\title{
REFORMASI TOTAL? LABOR AFTER SUHARTO
}

\author{
Vedi R. Hadiz
}

\section{Workers and 'Reformasi'}

Workers were late in joining with students in the tumultuous events of May 1998 that finally ended Suharto's thirty-two-year rule of Indonesia. Frustrated and bewildered by mass retrenchments, sky-rocketing prices for basic commodities, and a state-imposed wage freeze, workers found themselves too weak and disorganized to protest effectively against their increasingly dire economic situation. It was only about a week before the fatal shootings of Trisakti University students on May 12 that they showed any signs of being on the move again, with sporadic strikes and protests breaking out in the industrial areas of West Java. Eventually workers did combine with students in the five-day take-over of Parliament House, with even a delegation from the normally docile state-backed union, the FSPSI (Federasi Serikat Pekerja Seluruh Indonesia), present to demand Suharto's resignation in the very last days of his rule.

Suharto's fall has not immediately improved Indonesia's desperate economic situation, with new President Habibie's legitimacy questioned and investors fearful of a repeat of the mass rioting in May. An exodus of Chinese-Indonesians, as well as that of some foreign investors, occurred during the riots-these left at least 1,200 dead. The rupiah remains in tatters while basic commodities continue to be both increasingly expensive and scarce. ${ }^{1}$ By July, 40 percent of Indonesians, or about eighty million people, were regarded as living below the poverty line, ${ }^{2}$ compared to "just" 11 percent

1 One month after Suharto's resignation on May 21 the rupiah was at about 15,000 to the dollar, well over the 6,000 mark upon which economic planning for the year was premised.

2 Jakarta Post, July 3, 1998, p. 1. 
110 Vedi R. Hadiz

in 1996. Economically, Indonesians were back, in many ways, to standards existing decades earlier. ${ }^{3}$

The demand for a quick and thorough reconstitution of social and political life as a prerequisite for dealing with the economic crisis is still being made by various sections of Indonesia's fragmented but revitalized opposition. These demands are being made in spite of the Habibie government's insistence on a political transition period that would extend to the end of 1999.4 What would workers get, however, out of any process of reconstitution? What could they realistically hope to achieve amidst calls for reformasi total? Indeed, could they have a part at all in assuring change in their interests?

These are some of the questions that workers and labor activists have had to confront in the alternately heady and frustrating weeks and months following the fall of Suharto. On the one hand, the stagnation of Indonesia's economy had meant the loss of jobs-300,000 in the garments and textiles sector alone up to March 1998-and a concurrent further weakening of labor's bargaining position as hundreds of businesses continued to fold. ${ }^{5}$ Prior to the May riots, Indonesia's economy was projected to post a growth rate of minus- 5 percent, but this was soon after revised by analysts to anything between minus-10 to minus-30 percent, signifying massive unemployment and underemployment rates. ${ }^{6}$

Labor organizers keenly understood the difficulties they confronted in such a context. On the other hand, workers and labor activists were presented with a unique opportunity to push for greater freedom to organize as pressure grew for the unraveling of the long-entrenched framework that had governed state and society relations in Indonesia and which had been Suharto's main political legacy. Nevertheless, their organizational weakness prior to the economic crisis and the fall of Suharto meant that workers were constrained in their ability to exploit whatever opportunities were presented by the events of May. They are also arguably constrained by the fact that the current reformasi movement, itself highly fragmented

3 An ILO (International Labour Organization) report announced that 66 percent of Indonesians would be living below the poverty line in 1999. See International Labour Organization, Jakarta Office-United Nations Development Programme (hereafter ILO-UNDP), Employment Challenges of the Indonesian Economic Crisis (Jakarta: ILO, 1998), p. 48.

${ }^{4}$ Culminating in an MPR (People's Consultative Assembly) session to elect a president and vice-president in December 1999, following general elections the previous May.

5 The crisis has crippled hundreds if not thousands of local businesses. Labor-intensive, export-oriented manufacturing firms have shed their workforces as scores of factories either closed down or reduced production levels because of the spiraling costs of imported raw material and equipment. Moreover, up to the end of March 1998, one million workers had lost their jobs in the construction and property sector. Indonesia's troubled banking sector had also eliminated at least fifty thousand of its workers (Jakarta Post, March 26, 1998), due largely to the closure of many banks and forced efficiency measures. The mass exodus of multinational firms following the eruption of the May riots must have contributed to Indonesia's already long unemployment lines.

6 The IMF predicted a growth rate of minus-10 percent for 1998 (Kompas, June 26, 1998), compared to annual growth rates of about 7 percent prior to the economic crisis. But substantially more dire predictions have subsequently become common. Even in the most prosperous of times, a substantial number of new entrants in the job market were not absorbed into the economy. For one view on unemployment and underemployment, see ILO-UNDP, Employment Challenges, pp. 23-41. 
along different groups, is very much dominated by middle-class intellectuals and politicians with few links with the labor movement.

In spite of such limitations, worker activism has clearly been on the rise since the events of May leading to and following the fall of Suharto. According to Department of Manpower data, eighty-three strikes took place in June 1998,7 compared to just four in February, and such statistics must always be regarded as being on the conservative side. Workers were also soon preparing the way, amidst economic turmoil and political uncertainty, for the establishment of new independent unions. Talk of general strikes and even of the establishment of labor parties became rife in a manner quite unprecedented for decades. During strikes and demonstrations, placards and banners demanding freedom to organize were displayed side by with those demanding minimum wage increases and price reductions and those which proclaimed strongly "buruh lagi lapar!" (workers are hungry!).

The developments described above demonstrate the growing fragility of the institutional arrangement of state-labor relations in place during Suharto's rule, one that was already being exposed towards the last years of his tenure. These arrangements grew out of the perceived requirements of the New Order in its relatively early years, but were ill suited to accommodate growing demands as a new, more distinctly urban-based working class began to take shape after decades of sustained industrial development. There was increasing pressure to dismantle these arrangements as urban industrial workers with a greater propensity to organize began making demands for better wages and protection of various labor rights.

Perhaps the strongest evidence of this was the dramatic rise of strike action in the 1990 s after a long lull, notably in the mid-1980s. Government statistics suggest that 350 strikes occurred in Indonesia in 1996 compared to just nineteen in 1989, in spite of continually intense repression of labor activists. ${ }^{8}$ Independent organizing, though still unsophisticated, and growing labor unrest clearly confronted state labor policy, which had been premised on the maintenance of industrial harmony and which rejected conflict as a matter of principle.

The partial unraveling of state-labor relations as they have been constituted since the early New Order is now a more likely prospect than ever. An important facet of these relations was the curtailment of the right to organize by the upholding of the monopoly on labor "representation" by one state-backed and state-created union organization. This monopoly is now difficult to maintain. However, clear obstacles remain to the emergence of effective labor-based organizations capable of representing the interests of workers in the process of contestation and negotiation between social forces as political power is reconfigured in post-Suharto Indonesia.

\footnotetext{
7 Department of Manpower Statistics, 1998.

${ }^{8}$ Department of Manpower Statistics, various years. Non-government sources often cite figures several times greater.
} 


\section{Suharto's Legacy}

The reconstitution of organized labor in the early New Order took place as the result of a variety of economic and political considerations. There was no simple, functional correspondence between the economic aims pursued by the New Order and its labor agenda. But the maintenance of a politically moderate labor movement certainly benefited the pursuit of aims which included curbing inflation, attracting foreign investment and aid, and generally re-establishing connections with the world capitalist economy. The destruction of SOBSI (Sentral Organisasi Buruh Seluruh Indonesia), the largest and most well-organized labor federation, in 1965-66, meant that workers were basically powerless to influence policy-making, though remaining labor organizations were called on to assist the government to create a more "investorfriendly" image for Indonesia. Thus, non-communist labor unionists were dispatched to Europe in 1969 to convince foreign investors that it was "safe" to come to Indonesia, as workers were now "patriots bound to national interests."

The stringent controls over organized labor in the early years of the New Order were perhaps more directly the product of political considerations of the time. These involved the perceived need to effectively pre-empt the re-emergence of independent, militant tendencies within organized labor, given the historically strong links with the crushed Indonesian Communist Party (PKI). But eventually, even a merely effective labor movement was considered threatening, in spite of the absence of any real danger of a resurgence of the communist stream in the labor movement.

Founded by a coalition of forces led by the military, the New Order was premised on the destruction of the army's old foe, the PKI. While the conflict between the army and the PKI had earlier roots, ${ }^{10}$ the former's growing political, administrative, as well as economic role in the early 1960 s was pitting it increasingly against the communists. By this time, the PKI represented the army's only organized rival for political power, in spite of the vicissitudes of Indonesian party politics that directly affected it. ${ }^{11}$ Moreover, the army's assumption of managerial control over state enterprises in 1957 meant that it had developed a vested interest in the maintenance of industrial "peace," resulting in direct confrontation with the more radical unions associated with SOBSIthe labor federation connected to the PKI. But even before this, as early as 1950-51, the military was already engaged in an adversarial relationship with militant labor, then still buoyed by the euphoria of revolution that accompanied the newly completed independence struggle. Stoler writes that:

As early as $1950 \ldots$. . regional military commanders began issuing orders prohibiting work stoppages in the areas for which they were responsible. In February 1951 the Ministry of Defense superseded these regional ordinances with

\footnotetext{
9 As reported in Nusantara, July 30, 1969.

${ }^{10}$ It could perhaps be traced to the confrontation at Madiun in 1948 when the republican military forces sided with Soekarno and Hatta to quell the PKI (Indonesian Communist Party), then under the leadership of Musso. See Benedict Anderson, "Rewinding Back to the Future: The Left and Constitutional Democracy," in Democracy in Indonesia, 1950s and 1990s, ed. David Bourchier and John Legge (Clayton: Monash University, 1994), p. 132.
}

11 For example, President Soekarno's scrapping of Indonesia's liberal parliamentary system in the late 1950s, under which the communists had done so well. 
a national strike ban in all "vital" industries ... In August of that year an anticommunist campaign was started in the "interests of national security" with "arrests and large movements of tanks and armored cars in East Sumatra." Throughout Java and Sumatra communist literature was confiscated, "security sweeps" were carried out in towns, and in total 15,000 were arrested (Feith $1962: 188-89)^{12}$. But those rounded up during the razzia included many non-PKI supporters; in fact, they were drawn from a much larger base covering political activists expressing even vague sympathy with the labor movement. ${ }^{13}$

The PKI's decimation in the mid-1960s automatically meant SOBSI's own abrupt, violent elimination from the labor scene.

In 1973, as the culmination of a long and complicated process of elite-initiated maneuvers, the remaining labor organizations-former rivals of SOBSI that had mostly aligned themselves with the army-were forced to join a new, state-sanctioned federation. This was the FBSI (Federasi Buruh Seluruh Indonesia), later to be known as the SPSI (Serikat Pekerja Seluruh Indonesia) and then the FSPSI (Federasi Serikat Pekerja Seluruh Indonesia). ${ }^{14}$ With the establishment of the FBSI, links between the labor movement and political parties were formally severed.

Labor was then directed to confine itself to the strictly "social and economic" realm, ${ }^{15}$ something that contradicted its history of active political participation stretching back to the early nationalist struggle. ${ }^{16}$ In spite of the New Order's ideological aversion to the liberal/social democratic tradition of Western trade unionism, it clearly embraced the idea of the separation of the "social-economic" from the "political" in its domestication of Indonesia's previously vibrant and overtly political labor movement.

Indeed liberalism is regarded as being as much in contradiction to the "harmonious, family-based principles" of Pancasila as is communism. In fact, the doctrine of Pancasila Labor Relations, later renamed Pancasila Industrial Relations (Hubungan Industrial Pancasila; HIP), was presented as one that was supposedly uniquely suited to Indonesian culture and opposed to foreign-derived notions of class conflict. ${ }^{17}$ In Pancasila Industrial Relations, workers, capital, and the state were parts of one big family, with the latter playing the role of benevolent father. Consequently, even the legally recognized right to strike became stigmatized as "un-Pancasila" and "un-Indonesian," thereby providing cultural legitimacy for the political practice of suppressing labor unrest.

${ }^{12}$ Herbert Feith, The Decline of Constitutional Democracy in Indonesia (Ithaca: Cornell University Press, 1962).

${ }^{13}$ Ann Stoler, Capitalism and Confrontation in Sumatra's Plantation Belt, 1870-1979 (New Haven: Yale University Press, 1985), p. 142.

${ }^{14}$ See Vedi R. Hadiz, Workers and the State in New Order Indonesia (London: Routledge, 1997), pp. 71-82.

${ }^{15}$ See Agus Sudono, FBSI Dahulu, Sekarang dan Yang Akan Datang (Jakarta: FBSI, 1981), p. 26.

${ }^{16}$ See John Ingleson, In Search of Justice: Workers and Unions in Colonial Java, 1908-1926 (Singapore: Oxford University Press, 1986) and Takashi Shiraishi, An Age in Motion: Popular Radicalism in Java, 1912-1926 (Ithaca: Cornell University Press, 1990).

${ }^{17}$ See the ideas outlined in Ali Moertopo, Buruh dan Tani dalam Pembangunan (Jakarta: CSIS, 1975). 
Both the establishment of the FBSI in 1973 and the promulgation of Pancasila Industrial Relations were masterminded by Suharto's main political trouble-shooter at the time, the Machiavellian General Ali Moertopo, who also engineered the domestication and fusion of political parties in the same year. ${ }^{18}$ Indeed, meetings toward the establishment of the FBSI reportedly took place in the offices of BAKIN, the state intelligence coordinating body, one of Moertopo's bases of power. ${ }^{19}$

In 1985, under the direction of Minister of Manpower Sudomo (1983-88), a former security chief, the FBSI underwent a transformation into the even more centralized, hierarchical, and therefore more easily controlled SPSI. The change must be seen as a response to outbreaks of labor unrest in the late 1970s and early 1980 s amidst currency devaluations and recessionary trends. To the authoritarian Sudomo, the FBSI was apparently "too liberal" in structure, ${ }^{20}$ rendering it unsatisfactory as a tool of control, as evidenced by the outbreak of strikes.

It took another decade before another re-structuring took place, this time producing the FSPSI. The latter incarnation revived the sector-based union format that initially characterized the FBSI but which the establishment of much less autonomous "departments" within the SPSI had wiped out. The emergence of the FSPSI in 1995 was clearly yet another response to a new, though more serious, growth of labor unrest, as well as to the proliferation of alternative vehicles of worker organization.

Throughout these changes, labor has been presented in official rhetoric as a source of disruption to the political stability regarded as the essential pre-condition for economic success. Not surprisingly, the disruptive potential of organized labor was frequently asserted by alluding to the communist influence over the labor movement prior to the New Order's establishment. Thus, in 1967, the New Order's first Minister of Manpower, police General Awaloeddin Djamin, warned the "Indonesian nation and people" that labor would always present a problem, as long as the PKI was not completely smashed. ${ }^{21}$ In the same spirit, then Golkar Chairman General Sukowati warned that strike action could be exploited by PKI remnants. ${ }^{22}$

Even much later during the rule of Suharto, state officials, but military figures in particular, continued quickly to associate labor unrest with the work of communist insurgents. Admiral Sudomo was a particularly noted communist-phobe, even by New Order standards. But he was no friend of "liberals" either. At one time, he argued that the emergence of labor unrest in the 1990s was due to the adoption by "liberals" of "New Left" tactics. ${ }^{23}$ During Sudomo's tenure as Minister, the supra-national security agency Kopkamtib (Komando Pemulihan Keamanan dan Ketertiban) issued a questionnaire to workers that queried, among other things, their views on the

\footnotetext{
18 The United Development Party (PPP), an amalgam of Islamic-based parties, and the PDI (Indonesian Democratic Party) an odd admixture of nationalist, socialist, and Protestant and Catholic elements.

19 Interviews with Sutanto Martoprasono and Adolf Rachman, former FBSI functionaries, respectively, June 8 and June 28, 1994.

20 Sudomo as quoted by the newspaper Sinar Harapan, November 27, 1985.

21 Angkatan Bersendjata, March 3, 1967.

22 Antara, October 19, 1968.

${ }^{23}$ Interview with Sudomo, May 9, 1994.
} 
"attempted communist coup" of 1965, the involvement of any family members in the unrest, and their knowledge of Marxism-Leninism. ${ }^{24}$

The end of the Cold War did not do much to change this espoused fear of communist infiltration into organized labor. Following mass labor riots in Medan in 1994, independent unionist Muchtar Pakpahan was accused by military leaders of having a communist family background and of employing "communist tactics"; these accusations originated from powerful government figures, then-armed forces commander, General Feisal Tandjung and then-military chief of social and political affairs, General Hartono. ${ }^{25}$ Pakpahan was subsequently jailed while his organization became the target of repression. Labor observer Tom Etty recently recalled how for "twenty years" Indonesian government officials tried to convince him that "free trade unionism quasi-automatically would generate subversion, social unrest, and political agitation"-with the long-gone SOBSI being the usual point of reference for such arguments. ${ }^{26}$ Workers themselves sometimes convey how they are branded "PKI" by factory guards or military personnel during labor disputes.

As is often pointed out, military intervention into labor affairs has been pervasive during the New Order, though it did have clear precedents in the 1950s and 1960s when the military co-operated with anticommunist unions and even set up its own self-styled labor organization, SOKSI (Sentral Organisasi Karyawan Sosialis Indonesia). In 1986, Sudomo promulgated a ministerial decision that gave a legal basis for the military's role in labor affairs, particularly with regards to industrial disputes. Though this decision has been subsequently repealed, such a role continued to be condoned on the basis of a 1990 policy established by the head of Bakorstanas (Badan Koordinasi Strategis Nasional, whose leader is simultaneously commander of the armed forces), the security agency which succeeded Kopkamtib. According to the 1990 policy document, the military apparatus at all levels is given early detection, preventive and repressive functions to control labor unrest, powers much like those wielded by Koptamtib during Sudomo's heyday. ${ }^{27}$

That this "security approach" to industrial relations has meant widespread acts of violence and intimidation being practiced against workers has also been well documented. Military/security personnel have often been deployed to instill fear among workers, break-up strikes, and punish labor organizers. ${ }^{28}$ Those involved are also alleged to benefit materially from such interventions by receiving remuneration

24 "Kopkamtib Questionnaire for Workers," 1985. First published in Inside Indonesia 8 (October 1986), p. 8.

25 See Hadiz, Workers and the State, p. 172. Tandjung would later become Coordinating Minister for Politics and Security, while Hartono would become Army Chief of Staff and then Interior Minister. Habibie retained Tandjung in his latter post after Soeharto fell, while Hartono was sacked.

26 Tom Etty, untitled and unpublished paper for a conference on the Economic Crisis and Labor in Indonesia, Bandung, July 12-14, 1998.

27 Bakorstanas, Pedoman Penanggulangan Kasus Hubungan Industrial, 1990.

28 See, for example, Indonesian Information and Documentation Center, Indonesian Workers and Their Right to Organise (Leiden: INDOC, 1981, 1982, 1983, 1984); Human Rights Watch/Asia, The Limits to Openness: Human Rights in Indonesia and East Timor (New York: Human Rights Watch/Asia, 1994); Yayasan Lembaga Bantuan Hukum Indonesia (hereafter YLBHI), Indonesian Labour News: Repression and Violence Against Labour Continues (Jakarta: YLBHI, 1994). 
116 Vedi R. Hadiz

from employers to act on the latter's behalf during labor disputes. ${ }^{29}$ The violence accompanying their involvement in labor affairs is perhaps best symbolized by the highly publicized case of the brutal kidnapping, sexual assault, and murder in 1993 of Marsinah, the young woman who led a strike at a watch factory in East Java. Though the identity of her murderers has never been clearly established, it is widely believed that she was the victim of actions taken by the local military to quell labor unrest. ${ }^{30}$

In the context of such a security-heavy approach to labor affairs, the main function of the FSPSI and its previous incarnations has been to assist in prohibiting the development of labor organizing vehicles outside of the control of the state. Throughout a large part of the 1980s, for example, its officials openly took part in the ad hoc security teams set up by Sudomo to prevent and repress labor unrest, working closely with Kopkambtib. ${ }^{31}$ The union has also been, to an extent, "colonized" by the military, as numerous active or retired officers have been named to head regional and local branches. 32

Workers were also frequently constrained from freely organizing at the level of the firm. Thus, official workers' representatives at that level have sometimes turned out to be men with military backgrounds who work as company personnel managers, and thus technically pass as employees. According to one observer, retired military officers make good personnel managers in factories because, they "know how to control and manage people . . . ," and have "discipline." 33 Perhaps even more importantly to employers, they also "represent state power and control" and "instill fear among workers." Though this observation was made in Central Java in the 1980s, the practice of employing military men as personnel managers is prevalent elsewhere and in more recent times, including in the far more industrialized area of Greater Jakarta.

Not surprisingly, therefore, business has been complicit in attempts to constrain workers from organizing effectively. Business has been a conservative force, supporting for the most part the idea that stringent controls must be placed on labor and the need to keep it weak. Athreya notes that one prominent industrialist, Sofyan Wanandi (aka Lim Bian Koen) once proclaimed at a closed meeting that:

Yes, we underpay the workers. We must keep the workers weak. If they become too strong, if the military cannot control them, it is not the Indonesian

${ }^{29}$ See, for example, "Catatan Kasus Medan," YLBHI unpublished report, 1994. Also see the discussion in Hadiz, Workers and the State, pp. 174-76.

30 Yayasan Lembaga Bantuan Hukum Indonesia, Laporan Pendahuluan Kasus Pembunuhan Marsinah (Jakarta: YLBHI, 1994). The owner of the factory, a Sino-Indonesian businessman, was arrested and tried for the murder. While the courts eventually released him, he had already experienced severe beatings and torture by military personnel eager to obtain his confession and to dispel accusations of concerted military involvement in the affair.

31 See Richard Tanter, "The Totalitarian Ambition: Intelligence and Security Agencies in Indonesia", in State and Civil Society in Indonesia, ed. Arief Budiman (Clayton: Monash University, 1990), pp. 253-261

32 See Rob Lambert, "Authoritarian State Unionism in New Order Indonesia", Working Paper No. 25, Asia Research Center, Murdoch University, Western Australia, 1993, pp. 15-16.

33 Diane Lauren Wolf, Factory Daughters: Gender, Household Dynamics, and Rural Industrialization in Java (Berkeley: University of California Press 1992), p. 125. 
government or the US government who will suffer. It is we who will be destroyed. ${ }^{34}$

It is arguable that stringent controls over labor, often implemented with a generous level of violence, have contributed to the growing militancy of some sections of the industrial working class. The direct experience of confronting state power, represented by the security apparatus, has unwittingly helped to forge some sense of solidarity among workers who have participated in the more ugly instances of industrial disputes involving military personnel. Thus, informal leaders emerging from the rankand-file have often been young men and women who were sacked for their part in organizing strike action. During fieldwork in 1994, I encountered several "veteran" labor leaders-some of whom were young women just in their twenties-who boasted of encounters with the military which they survived and which seemed to raise their status among their colleagues. Branded "troublemakers," some of these "veterans" became full-time labor organizers, often working with NGOs.

\section{Contradictions in the Late Suharto Years}

The late Suharto years saw the monopoly of the FSPSI being increasingly challenged by the proliferation of local, often community-based organizing vehicles. Many, though not all, of these have operated in conjunction with labor-based NGOs. Several independent unions were also established, though none of them was ever particularly effective in terms of establishing a viable enterprise-level presence, given the difficulties in organizing at the workplace. The notable independent unions were Serikat Buruh Merdeka Setiakawan, formed in 1990 (but soon defunct), and the SBSI (Serikat Buruh Sejahtera Indonesia) formed in 1992, and led by Muchtar Pakpahan. Later, more radical student and labor activists established the PPBI (Pusat Perjuangan Buruh Indonesia) linked to the PRD (Partai Rakyat Demokratik)-suppressed after it was scapegoated for instigating widespread riots in Jakarta on July 27, 1996. State officials branded both the PPBI and PRD "leftist" or "communist" because of their employment of a radical critique of capitalism and their faith in the progressive political role of workers.

As mentioned earlier, at the same time that this wide range of formal and semiformal organizing vehicles began to proliferate, the frequency of strike action also increased quite dramatically. Most cases of strike action had to do with wage-related demands, though others involved health and safety grievances, solidarity for unfairly dismissed colleagues, as well as demands for the establishment of proper union representation at the enterprise-level.

Some state officials began to recognize the limitations of a strategy of control premised on repression. Thus, the use of the "carrot" was to be combined with that of

\footnotetext{
34 Bama Athreya, "Economic Development and Political Change in a Workers' Community in Jakarta, Indonesia", unpublished PhD thesis, University of Michigan, Department of Anthropology, 1998, p. 35. Here she cites personal notes taken from an American Chamber of Commerce meeting, February 1993. The "we" probably referred, in particular, to Sino-Indonesian businesses. The reference to the US was a response to strong external pressure at the time exerted on the Indonesian government to apply international labor standards.
} 
the "stick." This mainly took the form of a policy, implemented first by Minister of Manpower Cosmas Batubara (1988-93) and then his successor, the businessman Abdul Latief (1993-1998), to annually raise minimum wage levels. By 1997, the minimum wage was, in rupiah terms, practically three times that in 1990, though it was still only at about US\$ 2.50 per day. It is inconceivable that such a policy would have been introduced in the absence of rising labor unrest. Still, it was never fully effective in placating workers. On the contrary, strike action tended to rise each time that new minimum wage levels were to be put into effect, as workers protested against the hundreds of firms that typically asked to be exempted from the requirement to increase wages, citing economic difficulties.

The question of course remains as to why things heated up on the labor front the way they did beginning in the early 1990s, especially in the absence of effective, alternative labor organizations. Any general explanation must relate the rise of labor unrest to the great social and economic changes ushered in by the New Order through roughly three decades of sustained industrialization prior to the economic debacle of 1997. The emergence of a new urban industrial working class that developed a greater inclination to organize is inextricably related to this process.

Unlike their predecessors of earlier decades, contemporary workers no longer found the option of returning permanently to their home villages after brief stints in the city to be realistic or attractive, so they quite naturally have had more at stake in the success of urban-based life struggles. While ethnic, regional, and religious elements no doubt continue to be salient in the make-up of workers' self-identity, ${ }^{35}$ new forms of solidarity arguably began also to take shape among workers due to the growing awareness of the more or less permanent nature of their bleak urban existence. ${ }^{36}$ It is perhaps important not to exaggerate the transformation. The way that new worldviews evolve for a group of people and then guide their actions is undoubtedly always a slow and ambiguous process. In the case of contemporary industrial workers, this evolution has been intricately related to the changing material conditions of life and work for a growing number of young Indonesian men and women forced to contemplate relatively bleak futures in the context of clearly growing affluence for some. ${ }^{37}$ Significantly, due to the very process of economic development, they were also young men and women who were relatively better educated and had higher aspirations than their predecessors.

It was the adoption of a more export-led industrialization strategy in the 1980s, following the abrupt fall of international oil prices, that initially accelerated the process of change in the material conditions of life and work. The strategy was underpinned by the growth of a low wage, labor intensive manufacturing sector, in which young, female workers are predominant. Clearly, state planners were inspired by the success of the export-led model adopted by the first generation of East Asian Newly Industrialized Countries in the 1960 s and 1970 s, a model that was also initially

\footnotetext{
35 See Athreya, "Economic Development and Political Change," Chapter 3 and others.

36 But "cosmopolitan" middle-class Jakartans also display the same regional, ethnic, and religious loyalties, while few would suggest that they do not simultaneously display middle-class self-identities.

37 See the discussion in Hadiz, Workers and the State, pp. 124-32. For a dissenting view, see Athreya, "Economic Development and Political Change," particularly Chapter 3.
} 
grounded in such industries as textiles, garments, and footwear, capitalizing on a cheap and politically domesticated labor force. Manufacturing zones soon started to grow very quickly around major cities, particularly in Java, replete with vast, new slum areas populated by young industrial workers.

But the development of effective labor movements is supposed to be constrained by the very nature of the working class engendered by labor-intensive, export-oriented industries. Deyo, for example, writes that:

The attraction of young, low-skilled, often female workers to employment characterized by low pay, tedium, minimal job security, and lack of career mobility encourages low job commitment, high levels of turnover, and lack of attachment to work groups or firms. These circumstances impede independent unionization efforts among workers in light export industries ... 38

Some labor organizers in Indonesia often convey the same basic ideas when relating their on-the-ground experiences. However, the constraints to organizing that Deyo suggests are inherent to these industries may not be so completely insurmountable. The outbreak of strikes in Indonesia in the 1990s and the proliferation of independent labor organizing vehicles, mentioned earlier, demonstrate this to an extent. The same is demonstrated in the outbreak of labor unrest in the late 1980s and 1990 s in some of Deyo's own case studies, most prominently in South Korea.

\section{Organizing for "Reformasi"?}

In early May 1998, a group of activists associated with ICMI, the Association of Muslim Intellectuals, announced the formation of a union they called the Persaudaraan Pekerja Muslim Indonesia (PPMI). ${ }^{39}$ Whilst the move may simply be read as an attempt to develop populist credentials for the Habibie-linked organization-and to direct labor to more moderate forms of struggle-it did also anticipate developments which would take place soon after the fall of Suharto later that month.

Indeed, labor activists, especially those dissatisfied with both the FSPSI and existing independent unions, have for years been talking about the need to establish unions themselves. Some of these activists are now linked to new networks of worker groups, especially in the Jabotabek (Jakarta-Bogor-Tangerang-Bekasi) and wider West Java area. One of the main differences between these networks and others that existed previously is that they have more or less consciously limited the role of NGOs in their activities, in favor of developing a leadership emerging out of the rank-and-file.

Thus, in the more industrialized Greater Jakarta-West Java area, groups like KABI (Kesatuan Aksi Buruh Indonesia), KOBAR (Komite Buruh untuk Aksi Reformasi), and JEBAK (Jaringan Buruh Antar Kota) have emerged, all intent on forming new independent unions with a strong grassroots base. KABI, based in the Jakarta-BogorTangerang-Bekasi area, was particularly active in "representing" workers during the latter stages of the parliament house "take-over" in May. JEBAK, though strongest in

\footnotetext{
${ }^{38}$ Frederic C. Deyo, Beneath the Miracle: Labor Subordination in the New Asian Industrialism (Berkeley: University of California Press, 1989), p. 8.

39 Kompas, May 13, 1998.
} 
the industrial areas surrounding Bandung, has also developed pockets of followers in Greater Jakarta as well as several other regions. KOBAR, like KABI, active particularly in Greater Jakarta, but also with bases of support in other regions, has links with former PPBI-trained activists, and has maintained a close relationship with groups of radical students, particularly at the University of Indonesia. Similar networks of worker groups reportedly exist as well in East Java and South Sulawesi. In Surabaya, a labor union, the Serikat Buruh Reformasi, has been formed out of one of these networks. However, its base is confined to about twenty factories in the industrial areas surrounding the city. 40

JEBAK already formed its union by August 1998, while KABI established one during a congress in October 1998, emphasizing that its leadership is made up completely of rank-and-file workers. ${ }^{41} \mathrm{KOBAR}$ intends to follow suit. It is more than likely that others will be establishing labor unions with or without much regard for existing official guidelines regarding union formation. The lack of attention given to such regulations demonstrates the great skepticism among labor activists about the current government's professed reformist intentions.

In spite of such skepticism, the spirit of reformasi has not only brought out the "new" but also some of the "old." A new version of the Sarbumusi (Sarekat Buruh Muslimin Indonesia), for example, has been re-established by one of its old leaders, Sutanto Martoparsono. Reviving an Islamic-oriented trade union federation that was associated with the Nahdlatul Ulama (NU) political party from the 1950s till the establishment of the FBSI in 1973, the current Sarbumusi, however, remains quite marginal in today's labor movement and is not even supported by all sections of the NU itself. It apparently entertains the idea of re-establishing the old Sarbumusi's base amongst cigarette, food, and plantation workers. ${ }^{42}$ Another Islamic-oriented labor union, the aforementioned PPMI, also remains outside of the mainstream of the independent labor movement, as its leaders are generally perceived as being too closely associated with the powers-that-be through ICMI connections and its support of Habibie. It has tried to establish a base among a wide range of workers-including textiles and transport workers-partly by operating through working-class mosques. But it has also concentrated much effort on developing a following among more distinctly white-collar workers within the urban Muslim middle class. In addition, the PPMI tries to cultivate support among sections of the growing urban lumpenproletariat, and the informal sector, 43 particularly useful during its frequent staging of demonstrations. Theoretically at least, if not so clearly in practice, "sectarian" unions should be constrained by Minister of Manpower regulations that prohibit the establishment of unions on the basis of primordial allegiances.

Significantly, the labor movement in the 1990 s has been characterized by intensive interaction between NGO organizers who were sometimes Christian (due to the longestablished tradition of Christian social work) and rank-and-file workers, the vast

\footnotetext{
40 Discussion in Jakarta with Surabaya factory worker and SBR member, July 2, 1998.

41 Communications with KABI organiser, 14 October 1998.

42 Interview with Sutanto Martoprasono, Sarbumusi chairman, November 3, 1998.

43 Interviews with Eggy Sudjana and A. Deni Daruri, respectively chairman and secretary-general of the PPMI, November 19, 1998.
} 
majority of whom are Muslims. Organizations like SISBIKUM (Saluran Informasi dan Bimbingan Hukum) and Institut Sosial Jakarta (ISJ), for example, are clearly led by devout Protestants and Catholics, respectively, although they have worked with an industrial labor force which, at least nominally, has been predominantly Islamic. The SBSI, moreover, has been notable for the fact that its leader has a background in Christian mass organizations, yet it has in the past successfully included NU members among supporters. Given these recent experiences, the issue of religious divisions has not been especially prominent in discussions among workers about the future course of the labor movement and about the establishment of new organizational vehicles, although scores of political parties have been established on the basis of religious allegiances. Nevertheless, given the history of divisions in the pre-1965 labor movement, partly along religious lines, the way in which political allegiances on the basis of religious identity might later impact on labor organizing needs to be considered in further research.

Besides growing interest in forming unions, debate about the need for labor parties has also been rife. Ironically, members of the FSPSI took the initiative by forming the Indonesian Workers Party (PPI). Muchtar Pakpahan also has used the SBSI as a springboard to launch a National Labor Party with the intent to contest elections in 1999. The formation of these labor parties has taken place amidst the quick establishment of new political parties in general following the fall of Suharto and in anticipation of these elections. Many other labor groups, however, have dismissed the need for a labor party, arguing that it is most important for the union movement to exploit opportunities presented by reformasi and efforts to that end should be given priority. During recent discussions with workers, it has been evident that they have been much more excited about forming unions than political parties, regarding the former as a more directly useful instrument of protecting their welfare. ${ }^{44}$

This means, however, that workers will likely remain a "floating mass" in the elections scheduled for May 1999. There is no single labor organization with the "authority" to "negotiate" on behalf of workers with the various old and new political parties. At the same time, there is certainly no guarantee that workers will vote as a bloc for any of the new labor-based parties recently established..$^{45}$ Indeed, that these labor parties will contest next year's elections at all remains uncertain. In fact, only a fraction of the approximately one hundred new parties will likely be able to contest them if the stringent criteria established by a team that has formulated new political party and election laws on behalf of the Department of the Interior are not changed. The drafts they have produced are now the subject of intense debate. ${ }^{46}$

The establishment of a labor party by Golkar stalwarts within the FSPSI was one indication that the institutional arrangements of state and labor relations in place during Suharto's rule are being undermined. More recently, eleven of the thirteen

\footnotetext{
44 Various discussions with workers and labor activists in Jakarta, May and June 1998.

45 It would be less than speculative, however, to suggest that many urban workers, together with the urban poor in general, particularly in Java, would be inclined towards Megawati Soekarnoputri's PDI.

46 At least at one stage, the criteria have included the ability to set up branches in fourteen provinces and 154 of Indonesia's districts, and/or produce the signatures of support of no less than one million of the electorate. Such regulations clearly work against new, upstart parties without already existing local level machinery and sources of funding.
} 
industrial sector-based unions that comprise the FSPSI announced the withdrawal of their support for the organization's central board, thus largely leaving it a useless shell, at least for the time being. ${ }^{47}$ The sector-based unions have also indicated the possibility of forming a new union federation. Thus, pressure on the FSPSI to "compete" with other organizations is clearly growing as it watches its corporatist monopoly unravel.

The government has so far responded to these developments by offering more of the "carrot." New Minister of Manpower Fahmi Idris, eager to prove his reformist credentials, has announced a decision to raise the minimum wage by 15 percent, thus overturning a prior wage freeze called by his immediate predecessor, Theo Sambuaga (March-May 1998). ${ }^{48}$ Thus, in Jakarta for example, the minimum monthly wage is set at Rp 198,500, though at exchange rates prevalent in August this represented a mere US\$ 14.10.49

Idris also took the initiative so that Indonesia finally ratified ILO Convention 87 on Freedom of Association and Protection of the Right to Organize. At the same time, he announced ministerial decisions that, while stipulating strict regulations about the registration of unions at all levels with the Department of Manpower, in theory, provide greater room for the legal establishment of labor unions. ${ }^{50}$ In a step intended to bolster international credibility, Muchtar Pakpahan's labor union, the SBSI, was invited to register with the Department of Manpower within days of the lawyeractivist's release from prison in late May. ${ }^{51}$

But the "stick" also continued to be used quite freely against workers. Mass demonstrations planned by KOBAR and SBSI-linked workers in Jakarta, mixing traditional welfare demands with those connected to broader political reforms, were greeted with blatant acts of repression by the Jakarta military command. ${ }^{22}$ Later, twenty-three workers protesting at a factory in Bekasi, West Java, were shot with rubber bullets by security personnel in a tense and emotional industrial dispute. ${ }^{53}$ More recently, workers from Tyfountex, a partly Hong Kong-owned factory in Solo, were beaten by security personnel in Jakarta during a failed attempt to bring their wage-related grievances to the ILO representative. ${ }^{54}$ One worker at a JapaneseIndonesian producer of household goods related how in August 1998, he and four coworkers were arrested by police when their employers accused them of stealing from the company warehouse. Several of the workers were beaten at the local police station

\footnotetext{
47 Suara Pembaruan, August 22, 1998.

48 Jakarta Post, July 1, 1998, p. 1.

${ }^{49}$ Indeed, government officials acknowledge that the increase will do little to help workers cope with the expected inflation rate of at least 80 percent in 1998. It is estimated that the new minimum wage will only cover 75.8 percent of the "minimum physical needs" of a worker, compared to 95.32 percent before the economic crisis. See Jakarta Post, July 1, 1998, p. 1.

50 Jakarta Post, July 4, 1998.

51 Pakpahan was also invited to join the Indonesian contingent to the ILO's annual meeting in Geneva that June.

52 SiaR, June 26, 1998, received via Internet.

53 Xpos, no.27/I/July 4-10, 1998, received via Internet.

54 Xpos, no.35/I August 29-September 4, 1998, received via Internet.
} 
near Bogor, West Java, and all were only released after acquiescing to the officers' demand that each pay a bribe of $\operatorname{Rp} 500,000.55$

In spite of the burst in labor activity, there are reasons why workers cannot yet fully exploit the opportunities presented by the partial unraveling of the New Order. As mentioned earlier, the further weakening of labor's bargaining position in the context of massive unemployment growing out of the deepening economic crisis will surely affect success in organizing activity.

Labor activists obviously have little power to overcome the obstacles stemming from Indonesia's deep economic crisis. However, labor is also constrained by the inability of its active groups to forge greater levels of cooperation with one another, partly a legacy of the important role played by sometimes mutually competing NGOs involved in the labor movement. ${ }^{56}$ For example, it is obvious that some sort of "umbrella grouping" or even "confederation" of independent unions, at least embracing some of the major organizations, would be a more effective vehicle than a host of small unions working in an uncoordinated manner. Nevertheless, rivalries and lack of communication between different labor groups make the latter prospect more likely. While the existence of an array of semi-formal organizing vehicles without clear structures may have been advantageous in dealing with, or escaping from, state repression in the past, it remains to be seen whether they can really become the basis upon which more sophisticated vehicles can now develop.

Not surprisingly, labor activists have not really had an influence on the political opposition's agenda of reform, now mainly in the hands of middle-class politicians and intellectuals with few organic links with the labor movement. Labor alliances with the middle class have been confined to limited segments of the NGO and student movements. But some white collar employees of the banking, financial, and air transport industries, whose middle-class status is being threatened by the economic crisis, are now also planning to form their own independent unions. Such developments must be scrutinized more carefully over the following months and years to gauge the degree to which alliances with more significant sections of the middle class are possible through these avenues.

A third factor which negatively affects labor, the significance of which should not be underestimated, is the impact of economic globalization on the bargaining position of labor movements worldwide, but especially newly emerging ones in late industrializing countries. As widely recognized, economic globalization has been characterized by the growing mobility of international investors whose bargaining position vis-à-vis relatively immobile states and labor movements has been greatly enhanced. It has had much less discernible effect in stimulating international working class solidarity. If Indonesia recovers from the devastation of today's economic crisis (and if a global recession is averted) it will likely rely largely again on low wage export industries for growth. Globally mobile investment and, consequently, nationally based

55 Discussion, October 25, 1998. The amount constituted about two months' salary for him. According to this worker-now still under suspension-the FSPSI branch at the company where he has worked for nine years has not provided him or his colleagues any support or protection, though all have staunchly argued their innocence.

56 See Hadiz, Workers and the State, Chapter 7. 
labor movements with relatively weak bargaining positions, characterize these industries in particular. ${ }^{57}$

\section{Conclusion}

The domestication of labor as a social force has been part and parcel of the New Order's strategy of developing controls over and demobilizing society-based groups and movements. Restrictions on labor were put in place particularly because of the legacy of Left-wing and communist influence over the labor movement. In this sense, the institutional arrangements of state-labor relations in the New Order are a legacy of the struggles between the army and the Left prior to the mid-1960s. Indeed, state officials have often invoked the specter of communism to legitimize the repression of independent labor organizing activities.

Contradictions began to emerge as an industrial working class with a greater propensity to organize surfaced in the 1990s, partly as a product of three decades of sustained industrialization and economic development, prior to the current economic crisis that began in 1997. To deal with this development, the New Order opted for strategies that alternately emphasized the "carrot" and the "stick."

But the New Order's approach to its labor problems was still sufficiently repressive and security-heavy to alienate significant sections of the industrial labor force which continued to organize through an array of formal and semi-formal vehicles, ranging from aspiring independent unions to smaller community-based groupings. The possibility of officially recognized independent unionism was precluded throughout the Suharto years because it confronted the logic of demobilization and control which was the cornerstone of the New Order's political strategy.

The economic and political crisis in Indonesia opens up the unique possibility for the partial unraveling of the way that state and labor relations have been constituted. To seize this opportunity, workers are busy attempting to establish new organizing vehicles, in spite of the serious barriers already mentioned.

There is still one further obstacle that the fledgling independent labor movement needs to contend with: the government's adherence to a security approach that is intricately related to the military's long-standing role in social and political affairs. A system of industrial relations which is democratic, and in which the rights and dignity of workers are upheld, is not possible whilst a security heavy approach to labor problems continues to be practiced.58 The latter's elimination, however, is contingent upon a radical redefinition of the role of the military in social and political life, if not the abandonment of the "dual function" doctrine altogether.

57 See for example, Jeffrey A. Winters, Power in Motion: Capital Mobility and the Indonesian State (Ithaca: Cornell University Press, 1996), pp. 194-95.

58 As argued by Etty, unpublished paper. 